\title{
The Belt and Road Initiative and Its Perceived Impacts on the Textile and Garment Industry of Vietnam
}

\author{
Quoc An Le ${ }^{1, *}$, Van Ai Tran ${ }^{2}$ and Bao Long Nguyen Duc ${ }^{2}$ \\ 1 Green Ocean Institute, Nguyen Tat Thanh University, Ho Chi Minh City 700000, Vietnam \\ 2 Nguyen Tat Thanh University, Ho Chi Minh City 700000, Vietnam \\ * Correspondence: lequocan2001@gmail.com
}

Received: 24 June 2019; Accepted: 6 August 2019; Published: 22 August 2019

\begin{abstract}
The main purpose of this study was to find out the perceived impacts on the garment and textile industry of Vietnam from the Belt and Road Initiative (the BRI), a global-scale developmental and trade facilitation policy of China. The research applied both desk review and in-depth interviews with 54 leaders and high-ranked officials from public and private sectors in 2017 to identify potential impacts of the BRI on the Vietnam textile and garment industry. In addition, perceived challenges and opportunities of the BRI were also examined. Respondents from both sectors agreed that the initiative could foster textile export and the development of infrastructure. Apart from that, the main challenge is recognized as the poor competitiveness of Vietnamese textile firms on the international commercial playground. Solution insights that were offered through interviews suggested that the competence of domestic apparel brands and establishment of ODM (Original Design Manufacturing) and OBM (Own Brand Manufacturing) business models in Vietnamese textile producers may play the key roles in coping with the new challenges and in grasping opportunities that the initiative has to offer. From the perspective of the state, an improved public administration system is perceived as the key element in supporting the enterprises for upcoming challenges.
\end{abstract}

Keywords: The Belt and Road Initiative; the BRI; the One Belt One Road Initiative; the OBOR; textile and garment industry; Vietnam

\section{Introduction}

The Belt and Road Initiative (the BRI), a development and trade facilitation strategy proposed by China in 2013 to co-develop with a large area of 67 countries in Asia, Africa, and Europe, is an emerging factor for the overall regional economic development. The BRI identifies five interconnected pillars including strengthening policy communication, improving infrastructure interconnection, promoting trade facilitation, enhancing monetary circulation, and strengthening people's understanding about the BRI [1]. Among these measures, the most important dynamic is the soft loan from Chinese Financial Institutes to build up infrastructure (railway, freeway, sea port, energy industries), forming several economic corridors between China and countries in the BRI region. The improvement of infrastructure that supports accelerated and effective logistics could potentially be an important factor for economic development in developing countries in the BRI region, including Vietnam.

The Vietnam economy has been developing rapidly since 1986 with the adoption of the "open door and integrating global market" policy. For the past 30 years, Vietnam has maintained the annual economic growth of nearly 7\% in average. In 2018, Vietnam's Gross Domestic Product (GDP) was \$US 224 billion, while the value of gross trade was \$US 415 billion, accounting for $185 \%$ of GDP [2]. This suggests that Vietnam's economy has been depending largely on production of export products and supply chain, logistics, and communications should be paid special attentions by the Vietnamese government. 
The BRI will not only benefit economic development. In general, the initiative also facilitates the development of export-oriented industries such as the textile and garment sector, in particular. This industry has continuously grown in parallel with Vietnam's economy and played an important role. In 2019, the total value of exported textile products witnessed a $16.7 \%$ rise in comparison to 2018 and approximated \$USD 30 billion, accounting for $12.5 \%$ of national export turnover [3]. The Vietnam textile and garment industry and its export activities currently depend heavily on several key factors including globalization and market accessibility, supply chains of material and accessories, effective logistics, and updated technology, all of which are expected to be satisfied by the BRI. On the other hand, there are some concerns that the BRI may pose numerous challenges including fiercer competition in the domestic market and adverse environmental consequences caused by textile factories, which will be set up in Vietnam from the BRI investors.

China is a big player in the textile and apparel industry, whose collective production accounted for approximately $30 \%$ of the global textile production in 2010 [4]. This is mostly due to the cost advantage strategy that China focuses on. To be specific, China is promoting the production in key industries such as the textile material (cotton), the apparel (yarn, fiber, and fabric), the accessories, and supportive services (printing and dyeing, processing, design and development, logistics and distribution, wholesale and retail). This promotion strategy has led to over production and created critical environmental as well as domestic social problems [5]. Through the BRI, China plans to seek new outlets for their over-produced products, import cheap raw material, utilize cheap labor, and transfer pollution problems to the third-world countries.

The purpose of this study is to analyze the economic impacts of the BRI on the garment and textile industry of Vietnam in the context that Vietnam is located on the gateway connecting China to the Asia-Pacific region. To be specific, the analysis will seek to answer the following questions:

- Is the BRI beneficial to Vietnam's economy?

- How would the BRI impact the Vietnam Textile and Garment industry?

- What will be the key challenges for Vietnamese Textile and Garment Industry if Vietnam joins the BRI?

- What should Vietnam Textile and Garment enterprises do to grab the opportunities and/or limit the challenges coming from the BRI?

- What does the Government need to do to support enterprises to optimize the BRI?

\section{Literature Review}

\subsection{The Belt and Road Initiative: Contents, Plans, and Prospective Benefits}

Inspired by the historic Silk Road, President of China Xi Jinping, during his visit to Kazakhstan in September 2013, proposed the idea of setting up a "Silk Road Economic Belt" (SREB) [6]. The belt, situated along the Eurasian corridor, is an economic framework starting from Guangzhou City in the Guangdong Province, spanning through ten other cities in China and connecting with several Eurasian economic-trade centers such as Alma Ata (Kazakhstan), Dushanbe (Tajikistan), Tehran (Iran), Istanbul (Turkey), Moscow (Russia), Duisburg (Germany), Rotterdam (Netherlands), Venice (Italia), and other cities of Europe and Africa.

One month later, in October 2013, when visiting Indonesia, President Xi Jinping again came up with the idea of "The Maritime Silk Road" (MSR), also known as the 21st Century Maritime Silk Road, which is an economic and maritime network [7]. This road starts from Fuzhou City in the Fujian Province, passes through several southern Chinese ports, connects with cities in Southeast Asian countries, travels through the Malacca Strait to the cities in the west of the Indian Ocean, sails through the Red Sea, the Mediterranean, and finally arrives in Venice (Italy), from which it radiates to Nairobi (Kenya) as well as some other cities in Africa.

These initiatives were formally announced at the 22nd APEC Summit in Beijing under the official name of the "Silk Road Economic Belt" (SREB) and the "21st Century Maritime Silk Road" (MSR), 
referred to as the "One Belt One Road" (OBOR). At the 19th Congress of The Chinese Communist Party, OBOR was an important content of the development's strategy of China in the 21st century and was renamed as "The Belt and Road Initiative" (the BRI). The main goal of the BRI is to create an enormous commercial and economic corridor covering a population of 4.4 billion people (two thirds of the global population) and numerous nations whose gross domestic products occupies one third of the world's GDP.

Among five interconnected sectors of the BRI, infrastructure development (railways, highways, airports, seaports, telecommunications, energy pipelines, and warehouses) and industrial and sub-regional economic cooperation (mainly foreign-based industrial parks and economic corridors) are main contents of this huge initiative [1]. Other measures include strengthening policy communication, enhancing monetary circulation, and strengthening people's understanding through trade facilitation measures. To perform the initiative, gradual steps have been taken including: (a) putting the initiative into a national development strategy, (b) establishing the National Steering Committee led by President Xi Jing Ping, (c) pushing the participation of related provinces, and (d) identifying financial supports. The latter step involves establishing numerous financial institutions including Asian Infrastructure and Investment Bank (AIIB) with an initial capital of \$US 100 billion, in which China contributed $40 \%$, Silk Road Fund (SRF) with an initial capital of \$US 40 billion, and New Development Bank (NDB) in the BRICS (Brazil, Russia, India, China and South Africa) with an initial capital of \$US 100 billion, in which China contributed 41\% [8]. Many Chinese Banks such as China Development Bank, China Agriculture Bank, and China Import Export Bank were also ordered to preferentially finance the BRI projects. In addition, the participation of countries in the BRI region is also encouraged by China through lobbying activities including several forums on the BRI with the engagement of top national leaders.

The BRI plans to establish six corridors to prompt the accessibility to trade hubs. In addition, to accompany the infrastructure development, facilitation policies are also contemplated.

(i) The first corridor is named after the Eurasia "land bridge" as The New Eurasia Land Bridge Economic Corridor. This corridor involves a railway which connects Lianyungang (Jiangsu province) to Alashankou (Xinjiang province), passes Russia and several Eurasia countries, and finishes at Rotterdam in the Netherlands. To facilitate the railway, the Chinese Government has established secondary international railways connecting with the main route and offered new customs clearance schemes in which only single declaration and inspection is required for each cargo transported across the border by this railway.

(ii) The second corridor is the China-Mongolia-Russia Economic Corridor aiming at improving rail and highway connectivity between Russia, China, and Mongolia. The corridor also includes establishment of new infrastructures, expedited freight, and facilitated customs clearance.

(iii) The third corridor is the China-Central Asia-West Asia Economic Corridor which connects China with the Arabian Peninsula and runs through the territory of the Eurasian Economic Union [9]. The corridor mainly involves building railways covering Central Asian countries, Iran, and Turkey with possible extensions. In comparison with other corridors, this corridor is relatively settled, demonstrated by the completion of two huge railways, namely Angren-Pap and the China-Afghanistan railway. This plan also coincides with economic policies of several countries including Tajikistan, Kazakhstan, and Turkmenistan.

(iv) The China Indochina Peninsula Economic Corridor is the fourth plan aiming to strengthen connection between China and the Southeast Asia region [10]. The corridor is an established network achieved by collaborative construction of multiple rails and road transportation across countries including Vietnam, Cambodia, Thailand, Laos, and Malaysia. In addition, the initiative also incorporates new policies aiming for the harmonized development in the region. Of which, the most notable project is Greater Mekong Sub-region initiatives.

(v) The fifth corridor, namely the China-Pakistan Economic Corridor, involves the construction of highways, railways, pipelines, and fiber-optic networking running from Kashgar, Xinjiang, in northern China, to Gwadar Port in south Pakistan [11]. The pipelines play a particularly important role in this 
initiative since it will shorten the route of oil supplies from Middle East to China ports. Currently, the corridor receives favor from the Pakistan Government despite many security problems and political instability in Pakistan.

(vi) The sixth corridor is the China-Bangladesh-India-Myanmar Economic Corridor aiming at enhancing connection between eastern China with South Asian countries, especially India. However, the successful implementation of this corridor requires the unified attitude regarding multiple aspects such as financing, infrastructure establishment, and communication of participating countries. Even though this corridor faced opposition from India, initial investigation and discussion has been initiated between the four countries [12].

To date, several of these measures have been taken in a number of specific areas such as promoting the BRI locally and internationally, resulting in the establishment of international financial and currency connections and enhanced traffic connection and business linkages [6].

\subsection{The Belt and Road Initiative (BRI) and China's Strategic Advantages}

Although the BRI is a cautioned policy, especially when it comes to environmental issues [13], the policy is fully supported by the Communist Party of China. According to Wan, the BRI is considered as a strategy to achieve China's economic and geopolitical purposes, reaching Xi's "Chinese Dream", enhancing the economic impact to the region around China, and being in response to the restraint of US influence in the region [14]. Therefore, the BRI can be considered as the personal mark of $\mathrm{Xi}$ Jinping. China's strategic intentions include three main purposes as follows:

Firstly, the initiative is expected to address the issue of China's excessive production capacity, which poses a huge problem to the Chinese economy, and surmount difficulties in exploiting new markets for Chinese commodities [15]. Accordingly, China will connect trade, remove barriers, facilitate trade investment, improve infrastructure conditions, speed up the construction of a one-stop gate, encourage Chinese enterprises to invest in infrastructure abroad, and welcome foreign investment to China to promote closer trade links with Southeast Asia and South Asia, the Indian Ocean, and East Africa. This is especially important in the circumstances of the recent slowed growth of the Chinese economy which necessitates elevated export and reduced market pressures to reduce purchasing power.

Secondly, the BRI is targeted as the key tool to enhance access to resources from the BRI countries and the BRI neighboring areas [16]. The Chinese economy depends heavily on imported resources, which enter China through the sea. However, the transport channels are relatively undiversified. Cooperation between China and the major exporters of natural resources is still not deep and stable. Therefore, the BRI will dramatically increase the flow of resources, power on the roads, railways, and seaports, helping China secure supplies of domestic production through more transportation.

Thirdly, taking a larger role in global affairs with a China-centered trading network, the BRI not only helps China take over the economic influence on the region with the United States, but it also helps China to enhance its ability to govern the emergence of new rules in regional trade [17]. Through various infrastructure systems built on both land and sea, free trade agreements and financial institutions governed by China, it is foreseeable that in the long term China might have the power to control international trade affiliating with the BRI countries, maritime transport, valuation rights, as well as resource distribution. This ambition is especially important in the context of overcapacity of state-owned enterprises, which requires shifting into the BRI countries [18].

\subsection{Responses of Association of Southeast Asian Nations (ASEAN) and Non-ASEAN Countries to the BRI}

There have been different thoughts and reactions from countries inside and outside the region, both positive and skeptical. Many countries immediately applauded this idea, while the others are cautious, wanting to spend time researching or "waiting" to see what happens next before taking a formal stand [19]. The hesitation is based on four main questions: (i) Is the strategic objective of the Silk Road at Sea either purely economic or politically integrated strategy? (ii) If the focus is solely on economic benefits, what is the specific objective of the Silk Road? (iii) What is the specific 
implementation plan for the initiative (including the operation of financial assistance funds and the mechanisms for managing the formation of the Silk Route)? What is the impact of the Silk Route on the Sea to the region and the world?

The responses of non-ASEAN countries directly or indirectly related to the BRI can be divided into three main groups: (i) supporting groups who are unwilling to be excluded, including small and medium sized countries in South Asia, the Middle East, Africa, and Europe. They mainly need investment and market from China, (ii) Neutral groups who are mainly large and medium sized countries in the BRI region, including India, Russia, and the EU, and (iii) the opposing group including major non-BRI countries and concerned about China's regional and world-wide competition in the world, such as the United States, Western Europe, Australia, and Japan [20].

In the ASEAN region, there are also two main groups with different opinions towards the BRI [21]. The first group including Laos, Cambodia, Myanmar, and Thailand who unconditionally support the BRI. The second group also supports but still have some concerns, including Malaysia, Indonesia, Brunei, and Singapore.

For Vietnam, the government sees the BRI as a positive prospect in the context of being in desperate need for infrastructure investments and thus, supports the initiative diplomatically [22]. However, the BRI loans will be reluctant and carefully contemplated. So far, no project taking place in Vietnam has been officially recognized as BRI-funded. Apart from stringent criteria of the BRI loans and the lack of competence of Chinese contractors, the hesitation is mainly contended by concerns regarding South China Sea disputes and underlying political ambitions of China.

\subsection{Potential Impacts of the BRI on the Textile and Garment Industry of Vietnam}

The Vietnam Textile and Garment Industry is one of the most important economic sectors of Vietnam. According to the report of The Vietnam Textile and Apparel Association (VITAS), the industry has over 6000 enterprises with over 2.5 million employees and its export turn-over has been growing at an average annual rate of $18 \%$ since 2002 [23]. More than 100 countries regularly import textiles and garments made in Vietnam, of which the United States accounts for about $48 \%$, EU countries account for about $15 \%$, Japan $12 \%$, South Korea $10 \%$, Southeast Asia countries 3\%, and the rest was China and other countries. In the domestic market, textile and garment products also occupy a significant portion. In 2016, the consumption value of textile and garment products in Vietnam was \$US 16 billion, of which domestic production was about $70 \%$ and the rest was imported from China, India, Thailand, Taiwan, Korea, Japan, and Western countries.

However, this important industry has developed unevenly [24]. Garment production is the most developed part while the production of textile and raw materials have grown at much lower rates. Therefore, the Vietnamese textile industry must import a large quantity of raw materials and fabrics. In 2018, the export turnover of this industry was \$US 31.1 billion while its total import value was \$US 19.1 billion. There are four kinds of materials and accessories that were imported with large volume: fabric (\$US 11.4 billion), garment accessories (\$US 3.4 billion), raw cotton (\$US 2.5 billion), and synthetic fiber and yarn (\$US 1.8 billion). Most suppliers of fiber, yarn, fabric, and accessories are from Asian countries (e.g., China, Taiwan, Hong Kong, Japan, India, Pakistan, Thailand, Indonesia, and Malaysia). Raw cotton is mainly supplied from the USA.

It is without doubt that the BRI would have a significant impact on regional textile and apparel businesses. The first and probably the most important contribution of the BRI is the development of supply chains. The present structure of the Vietnamese textile industry indicates that supply chains that link manufacturers with materials suppliers and/or buyers play important roles as only garment manufacturers who set up good supply chains can do FOB, ODM, and OBM business. (FOB (Free on Board), the business model of selling products on board with design of buyers, ODM (Original Design Manufacturing), the business model of FOB plus own design, OBM (Own Brand Manufacturing), the business model of ODM plus own brand name). Those who cannot obtain good supply chains could only do cutting and sewing $(\mathrm{CM})$ business, which is much less profitable. Currently, there are 
still about $70 \%$ of garment manufacturers in Vietnam doing CM business, about $20 \%$ doing FOB business, and only about 10\% doing ODM and OBM businesses. Establishing supply chains is therefore the key for garment manufacturers in Vietnam to change from CM to FOB, ODM models that meet international buyer's requirements.

Another contribution of the BRI that could enhance competitiveness and improve the integration of the Vietnamese textile market to the international playground is globalized logistics. One of the pillars of the BRI is the connectivity which contributes the development of global value chains. According to the World Bank's study, while it takes 8 days to export within G7 economies, it takes about 18-50 days on average to export within Central and Western Asia countries [25]. It is expected that the BRI shall significantly reduce the transport time from Asia to Germany from 40 days to 15 days. As a result of expedited logistic services, market penetration strategies of retailers in China and Asia could be significantly accelerated and apparel manufacturers in Turkey, East European, and former CIS countries who are thriving because of faster delivery times to Western European markets, might find themselves at a disadvantage. In addition, the Chinese textile and garment sector might well move many existing factories to the BRI economic corridors. Given the changing nature of global production patterns, the availability and quality of transport infrastructure and services are critical for linking to the global value chain [26].

\section{Research Methods}

In this study, desk-review and in-depth interviews were used to find out the impacts of the Belt and Road Initiative on the textile and garment industry of Vietnam. Fifty-four informants from public sector, textile and garment associations, and academic institutions and enterprises in the garment, trading, and logistics industry participated in this study. When coding interview findings, it was found that opinions from the seven aforementioned groups were polarized contingent on the sector in which the respondent was. Therefore, research findings would be grouped into two main groups: results from public organizations and from private organizations.

To be specific, affiliations that are involved in the study are listed as in Table 1 and composition of the sample respondents are illustrated in Figure 1:

Table 1. Organizations that are involved in the study.

\begin{tabular}{cccc}
\hline No. & Affiliations & Sector & No. of Informants \\
\hline 1 & Ministry of Industry and Trade (MOIT) & Public & 2 \\
2 & Multilateral Trade Policy Department (belonging to MOIT) & Public & 1 \\
3 & Agency of Foreign Trade (belonging to MOIT) & Public & 1 \\
4 & ROO Division (belonging to MOIT) & Public & 1 \\
5 & Light Industry Department (belonging to MOIT) & Public & 1 \\
6 & Asia-Pacific Market Department (belonging to MOIT) & Public & 2 \\
7 & Diplomatic Academy of Vietnam-Ministry of Foreign Affairs (MOFA) & Public & 2 \\
8 & VEPR Chinese Economic Studies Program (VCES)-Vietnam Institute & Public & 1 \\
9 & for Economic and Policy (VEPR) & Public & 2 \\
10 & Vietnam Chamber of Commerce and Industry (VCCI) & Public & 3 \\
11 & Vietnam Textile and Apparel Association (VITAS) & Public & 1 \\
12 & Vietnam Cotton and Spinning Association (VCOSA) & Public & 3 \\
13 & Vietnam National Textile and Garment Group (VINATEX) & 1 \\
14 & Vietnam Leather, Footwear and Handbag Association (LEFASO) & Public & 18 \\
15 & Enterprises in the garment industry & Private & 9 \\
16 & Enterprises in the garment trading industry & Private & 6 \\
\hline
\end{tabular}




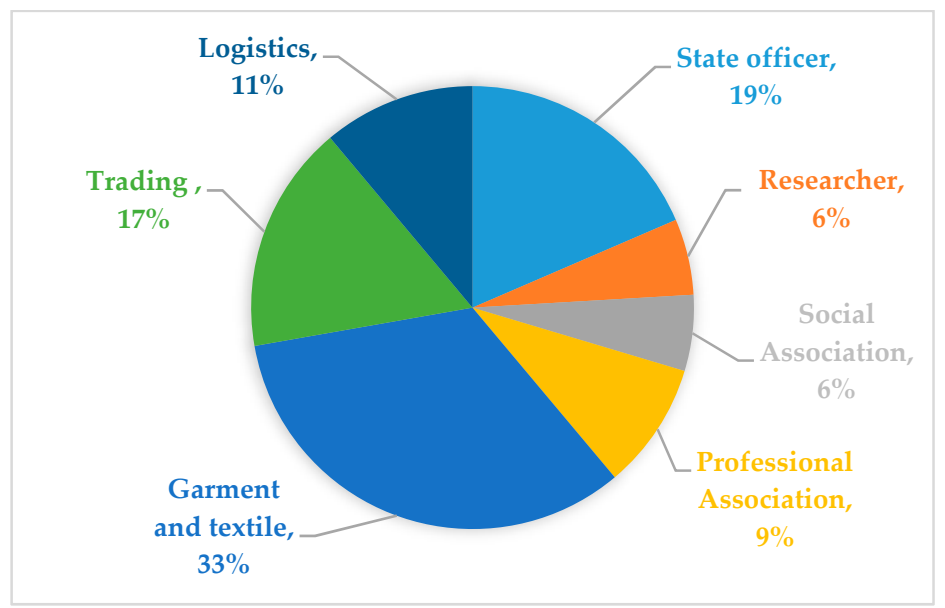

Figure 1. The composition of the sample respondents (Source: Authors' analysis).

\section{Results}

\subsection{Awareness about the BRI}

Figure 2 showed that the majority ( $89 \%)$ of respondents were aware of the BRI. Still, this program is unknown to $1 / 10$ of the target respondents, all of whom come from private sectors (garment enterprises, trading company, and logistics). Interestingly, most of the Vietnamese enterprises who were interviewed have established strong markets in the US and Europe, where the threats and incentives to expand existing markets are non-existent.

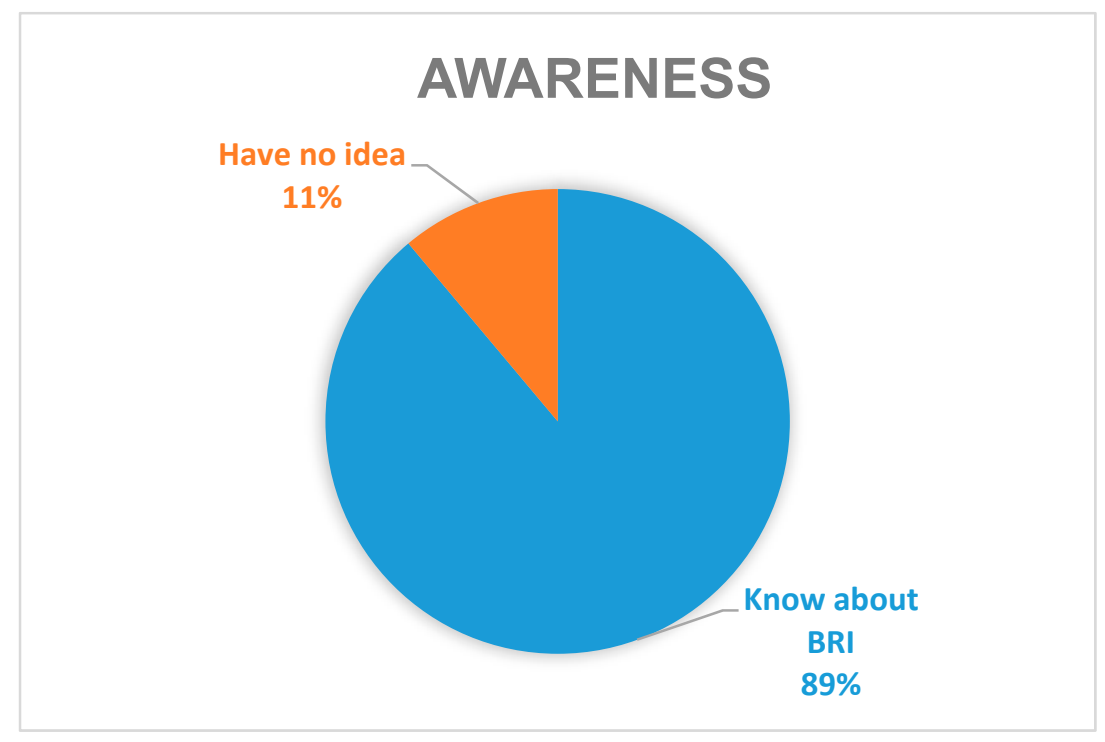

Figure 2. Respondents' awareness about the Belt and Road Initiative (BRI) (Source: Authors' analysis).

The main implications for the BRI were perceived as follows: $76-79 \%$ of respondents in both public and private sectors believed that the BRI's main function is to connect infrastructure while $81 \%$ of public sectors believe that the BRI is a form of economic and political linkage. At the same time, $82 \%$ of respondents from the private sector said that the connection and increase of trade competitiveness is the core content that the BRI brings in the future for Vietnam (Figure 3). 


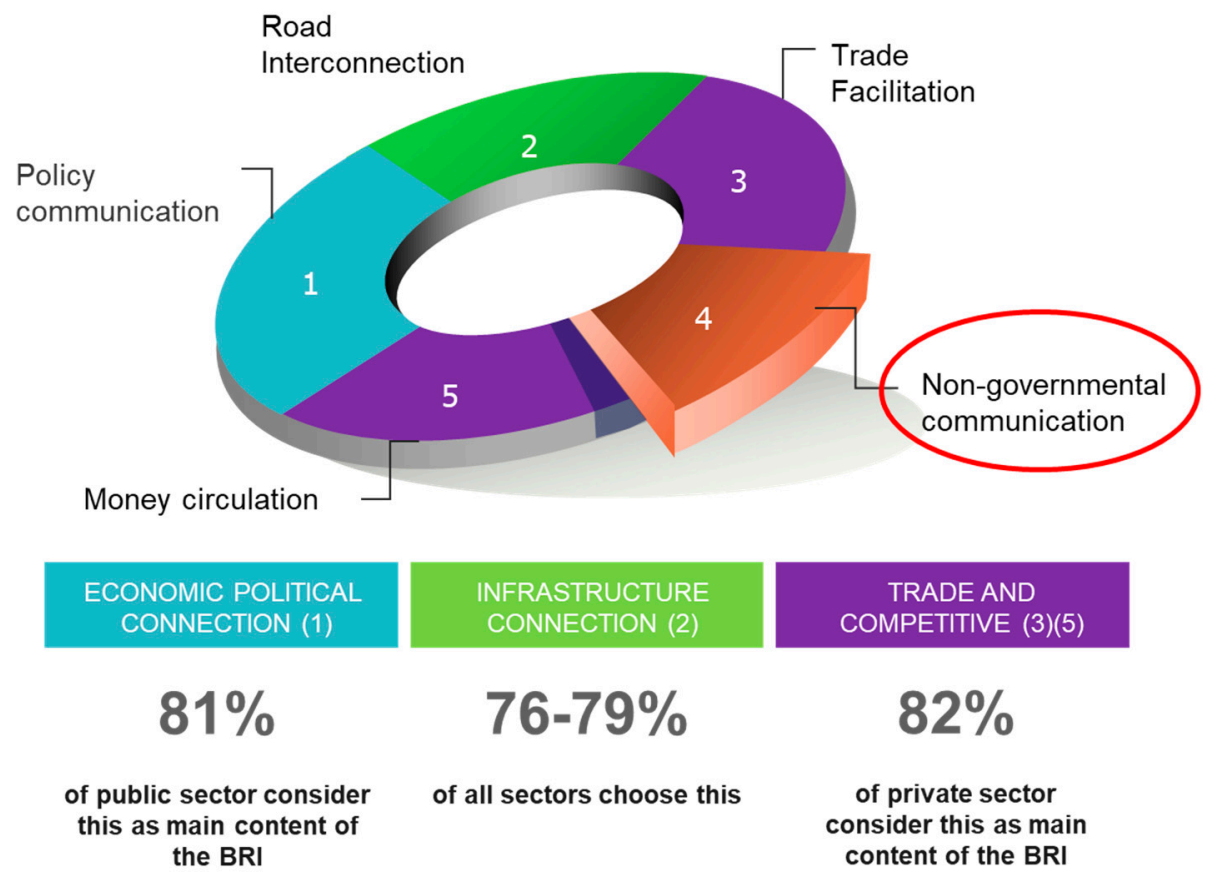

Figure 3. Respondents' understanding about the BRI (Source: Authors' analysis).

\subsection{The BRI has Significant Macro Benefits yet also Raises Key Concerns to the Economy}

The BRI is believed to be opportune for Vietnam's economy in general and for the textile industry in particular. Indeed, over $60 \%$ of respondents in both groups said that the initiative will be impactful for the development of the infrastructure in Vietnam (Figure 4). More than $52 \%$ of respondents in the public sector judged that the BRI would foster the development the Vietnamese economy. Over $60 \%$ of respondents in the private sector believed that the BRI would help strengthen the value chain in the region, especially in the relationship between Vietnam and China. Since then, Vietnamese merchandisers would be more competitive in exporting to markets involved inside and outside the BRI region. Other positive impacts may include: benefits from the BRI cargo transport across Vietnam and the ability to attract more foreign investment to strengthen the supply chain that supports Vietnam getting more comparative advantages.

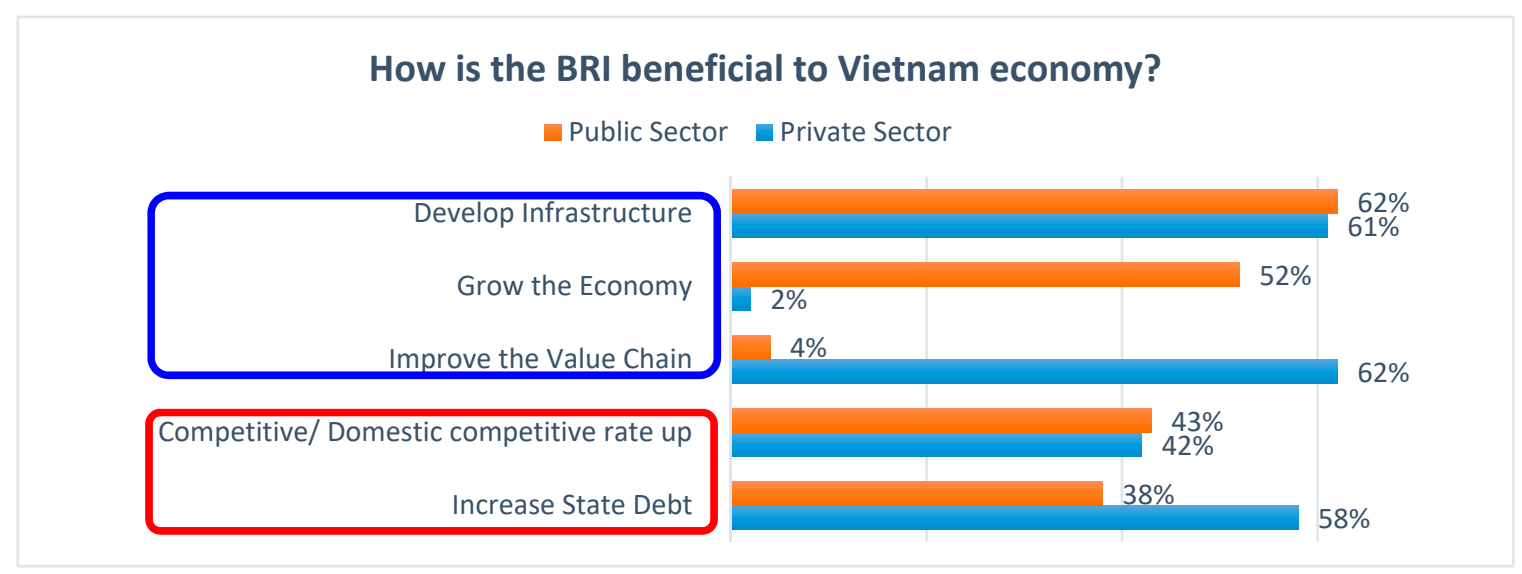

Figure 4. Perceived macro-level benefits and key concerns to the economy (Source: Authors' analysis).

Infrastructure improvement is the key common benefit to all sectors. Economy growth and value chain improvement are also strongly perceived by public and private sectors, respectively. 
However, the BRI also simultaneously bring challenges to Vietnam as over $40 \%$ of respondents said that the BRI would exert competitive pressure on the domestic market, leading to greater trade surpluses from China. Indeed, the trade surplus from China to Vietnam reached over \$US 40 billion in $2016.38 \%$ of those interviewed in the public sector and nearly $58 \%$ of those in the private sector perceived the BRI as a potential promoter of government debt.

Interestingly, when discussing the benefits, most respondents also share their concerns on competition capabilities of local enterprises and the elevation of state debt. In addition, the challenge of utilizing loans from AIIB and Chinese banks may be accompanied by unfavorable conditions for Vietnam about China's supply of goods and services. The environment in Vietnam can be adversely affected by the uninformed selection of investment projects and the lack of competent environmental management in Vietnam. Another obstacle that affected the trust of joining the BRI is the conflict between Vietnam and China in East Sea, as reflected by a comment of a respondent.

The closer China is, the more cautious it is to support the BRI by seeing China's ambitions reflected in its aggressive actions in the South China Sea and East China Sea. (Tran Viet Thai, a respondent and a researcher from Diplomatic Academy of Vietnam-Ministry of Foreign Affairs-(MOFA))

\subsection{Export Opportunities for the Vietnam Textile and Garment Industry}

Besides market access, the development of the textile and garment business in Vietnam in this time could benefit from the growth of supply chains, infrastructure, logistic systems, and human resources, which in turn could be supported by the BRI (Figure 5).

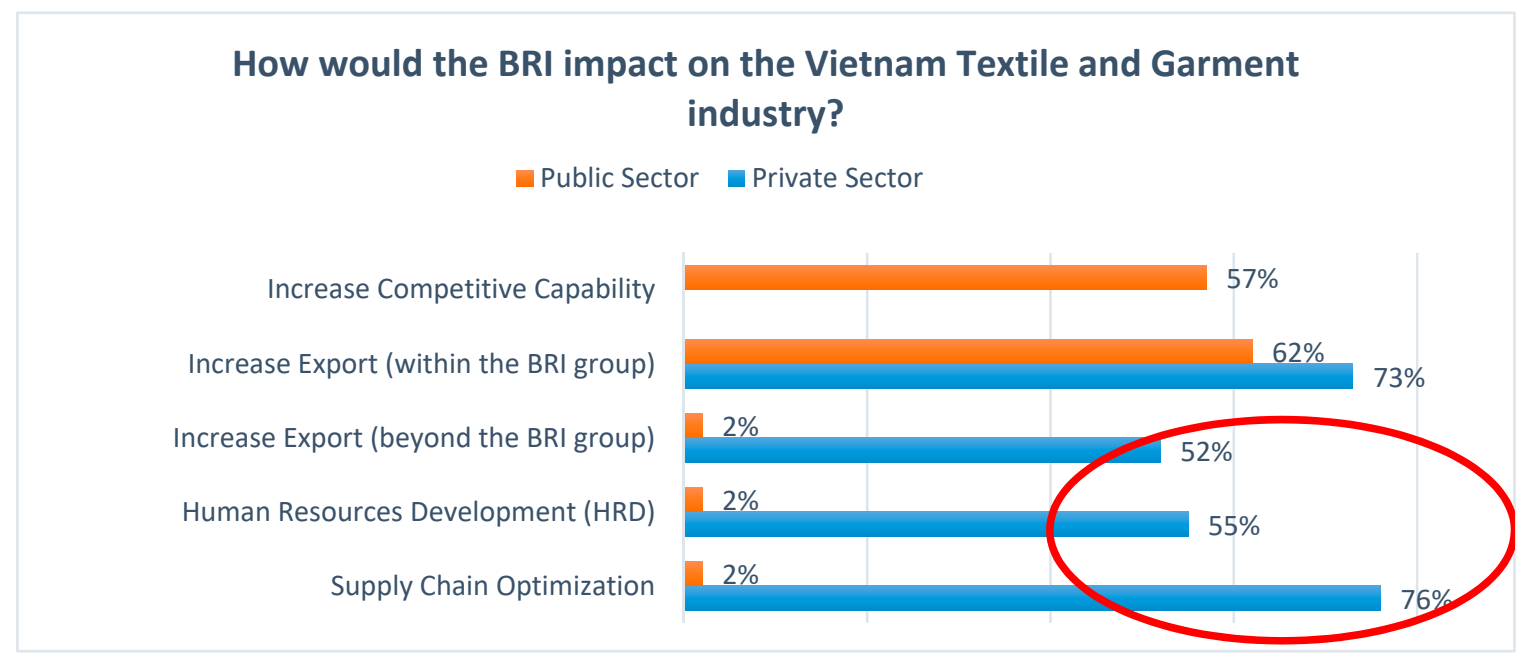

Figure 5. Export opportunities for the Vietnam Textile and Garment industry (Source: Authors' analysis).

Firstly, infrastructure including high-speed train, freeway, and seaports connecting Vietnam with neighboring countries can be built quickly with soft loans of financial institutions in the BRI framework. Consequently, logistics in Vietnam can be improved with the competitive cost of transportation. Secondly, the BRI will facilitate the flow of transaction of abundant materials accruing from textile manufacturing in the region, establishing more vertical and horizontal supply chains. Thirdly, industrial zones for textile with environment abatement facilities can be built with soft loans from the BRI. This sustainably satisfies the huge demand of garment's manufacturing in the time being by contributing to the development of materials and fabric made in Vietnam. Fourthly, the initiative could facilitate the movement of people in the region and support the Vietnamese textile industry in terms of human resources.

These reasons partially explain why $57 \%$ of respondents believed that the BRI would enhance the export competitiveness of Vietnamese garment and textile products. $52 \%$ of respondents from the private sector believed that the BRI would also promote Vietnamese garment export to other markets 
outside the region. $76 \%$ of those in the private sector said that the BRI would strengthen the link of the supply chains in the regional textile and garment industry, thereby increasing the competitiveness of Vietnamese textile and garment products. $55 \%$ of those in the private sector saw the BRI as an opportunity to enhance the quality of human resources in the Vietnamese textile and apparel industry. Some other comments related with transportation's infrastructure and technology articulated that the initiative would help reduce production costs, increase competitiveness, attract more investment in the production of raw materials and accessories, and encourage the textile and garment industry to develop towards a more balanced direction.

Export opportunities within the BRI group seem to be obvious. However, the public sector is more conservative due to concerns regarding domestic competition. The private sector, on the other hand, shows the thirst to get more exposure to learn and improve across areas (Human Resources Development, Supply Chain) and confidence to gain opportunities beyond the BRI group.

The BRI is a golden opportunity that Vietnamese government and enterprises should fully exploit for development. We can build up quickly logistic infrastructure and non-polluted industrial zones for textile to support the sustainable development of the textile and garment industry in Vietnam. (Tran Van Tuan, chairman of Vietnam Cotton and Spinning Association-(VCOSA))

This is consistent with another respondent, the vice chairman of VCOSA, who shares similar views on the export opportunity for Vietnam that may arise when China has to bring enterprises outside of the country to avoid over production and environmental problems. Another problem is that most Chinese cotton are planted in Tibetan and Xinjang, areas with unstable political conditions and a constant shortage of water which leads to a high cost of raw materials. As a result, a shortage in the stock of cotton will elevate production costs and shrink import quantities, creating an opportunity for Vietnam to export cotton materials. In response to this, the Vietnam National Textile and Garment Group (VINATEX) started the construction of the Rang Dong Industrial Textile Park in April 2018 in the Nam Dinh province which covers 2109 hectares and will become the biggest textile production zone in the Southeast Asia region. Nam Dinh is also the home of 480 textile enterprises with an estimated workforce of 70,000. The goal is to produce 1 billion meters of fabrics in 2020 and 1.5 billion meters by 2025. Wastewater treatment facilities with a daily capacity of 110,000 cubic meters will also be built within the park to meet with international environmental regulations.

\subsection{Competencies to Be More Competitive in an International Playground Is the Key Challenge}

The BRI may threaten competitiveness in the local market and pose the risk of environment pollution. The Vietnamese domestic market of fashion items is quite large with the average consumption of USD 170/person/year in 2016, in which 70\% could be satisfied from local manufacturers. With business facilitation of the BRI, imported goods can surge into Vietnam and compete fiercely with domestic production. On the other hand, the flow of Foreign Direct Investment (FDI) that moves into Vietnam more quickly to adapt the need of the industry's production can be a disaster for Vietnam's environment if its environmental consequences are not well managed. Figure 6 demonstrated main challenges faced by Vietnamese enterprises in the circumstances of increased competition.

From in-depth interviews, we found that a majority of respondents $(61 \%)$ in the private sector and $48 \%$ of those in the public sector believed that domestic garment enterprises would face competitive pressure domestically if the BRI takes place. $62 \%$ of respondents in the public sector said that the problem of environmental pollution would be a major problem that needs to be strictly managed. $73 \%$ of interviewed garment enterprises in Vietnam said that they will be under great competitive pressure from FDI and 53\% of interviewees were concerned about the inadequate support policy from the State. In general, the public sector shows concern about the environmental impact while the private sector insists on weak support in the supply chain by Vietnam's government.

The BRI will have positive impacts on the development of Vietnam's textile and garment industry in the 21st century. With The BRI, the industry can get an additional annual growth rate of 2-3\%. 
But at the same time, it can have unpredictable consequences on the sustainable development in Vietnam when environmental issues from textile factories are not well managed. (Vu Duc Giang, Chairman of the Viet Nam Textile and Apparel Association-VITAS)

Indeed, the textile industry generates a considerable amount of pollutants and accounted for approximately $5.4 \%$ of global carbon emission in 2015. In addition, effluent discharged by the industry also occupies approximately $20 \%$ of contaminated water in the world [26]. As the manufacture of textile products involves the use of carcinogenic and toxic agents, more stringent policies regarding proper treatment and abatement are required to anticipate the upcoming production boom and ensure the sustainability of the environment.

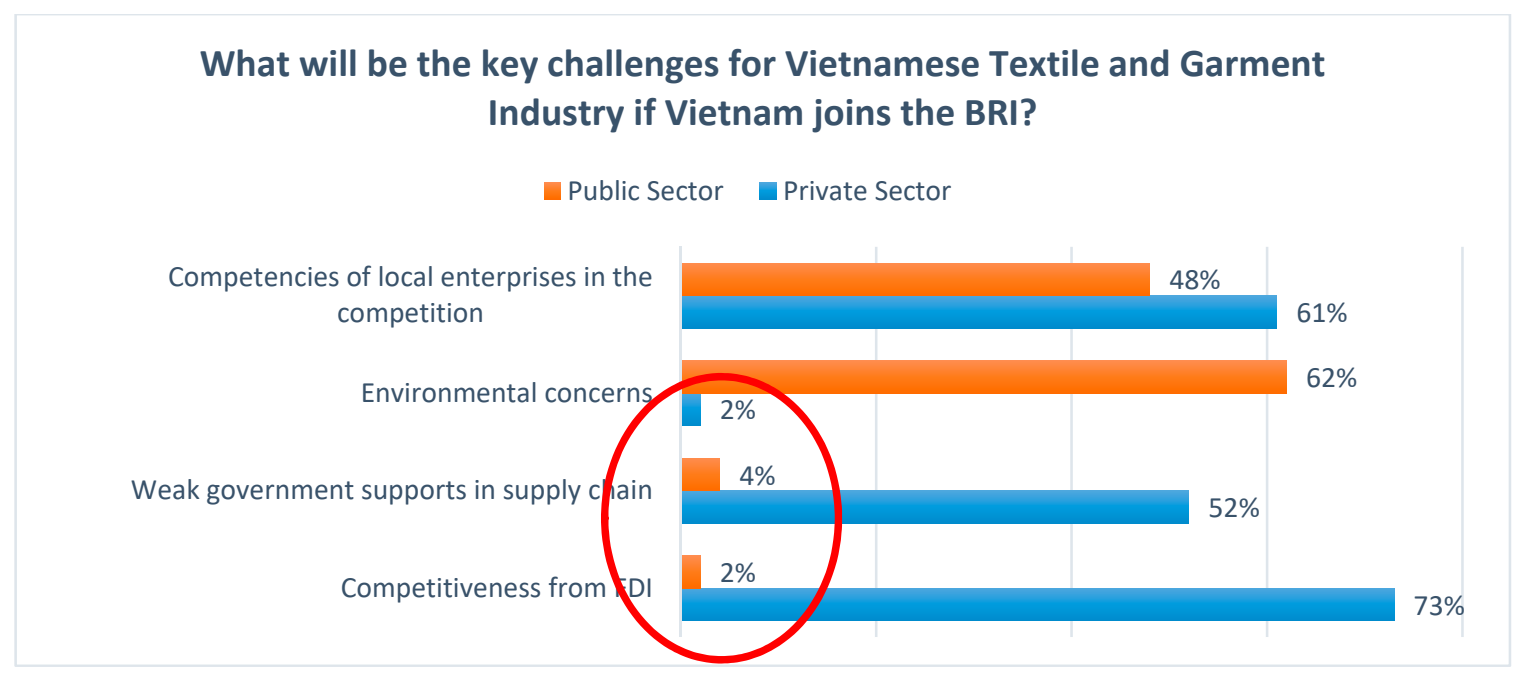

Figure 6. Competencies to be more competitive in an international playing field is the key challenge (Source: Authors' analysis).

\subsection{Actions Taken by Vietnam}

Human resources development, supply chain improvement, and local brand re-enforcement are considered as the most critical actions. Respondents of the survey recommended some actions that need to be taken by Vietnamese garment and textile companies (Figure 7). The majority of respondents from the private sector ( $82 \%$ ) and public sector $(62 \%)$ believed that training and building human resources is a top priority. Besides, $71 \%$ of the respondents from the public sector and $58 \%$ of those from the private sector suggested that businesses should invest in supply chain development. To be specific, respondents suggested that the investment in streamlining fabric production should be prioritized. Also, $82 \%$ of respondents from the private sector and $67 \%$ of those from the public sector believed that Vietnamese businesses should pay attention to branding in the domestic market. Moreover, 79\% of the respondents from the private sector said that businesses should quickly switch their apparel business practices from $\mathrm{CM}$ to FOB and ODM. Besides, $61 \%$ of the private sector also considered applying the 4.0 technology innovation to production and business to increase productivity. However, these two issues concerning model switching and application of technology innovation were neglected by respondents in the public sector.

Actions taken by the Government were also recommended by respondents from the private sector taking part in the survey (Figure 8), including: $82 \%$ recommended focusing on state administrative procedures to support business. $61 \%$ of them require support from the government to develop human resources while $79 \%$ of them desired to get preferential loans for investment. Besides, $63 \%$ of respondents from the private sector suggested that the Government should pay attention to negotiating more FTAs with the EU, the US, and South America. From the public sector, $71 \%$ of respondents saw 
that a more efficient state management system is needed, and the quality of management of ODA, especially from Chinese institutions, should be upgraded and strictly controlled.

\section{What should Vietnam Textile and Garment enterprises do to grab the opportunities and/or limit the challenges coming from the BRI?}

Public Sector $\quad$ Private Sector

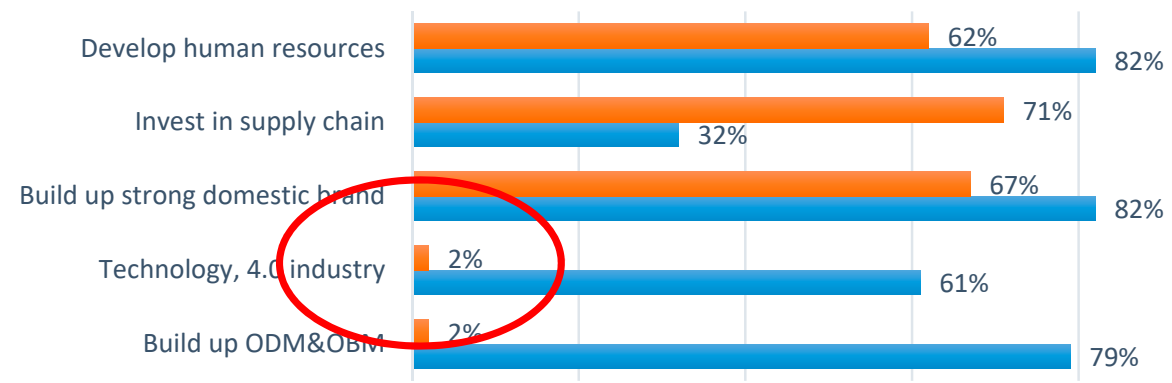

Figure 7. Expected actions taken by Vietnam (Source: Authors' analysis).

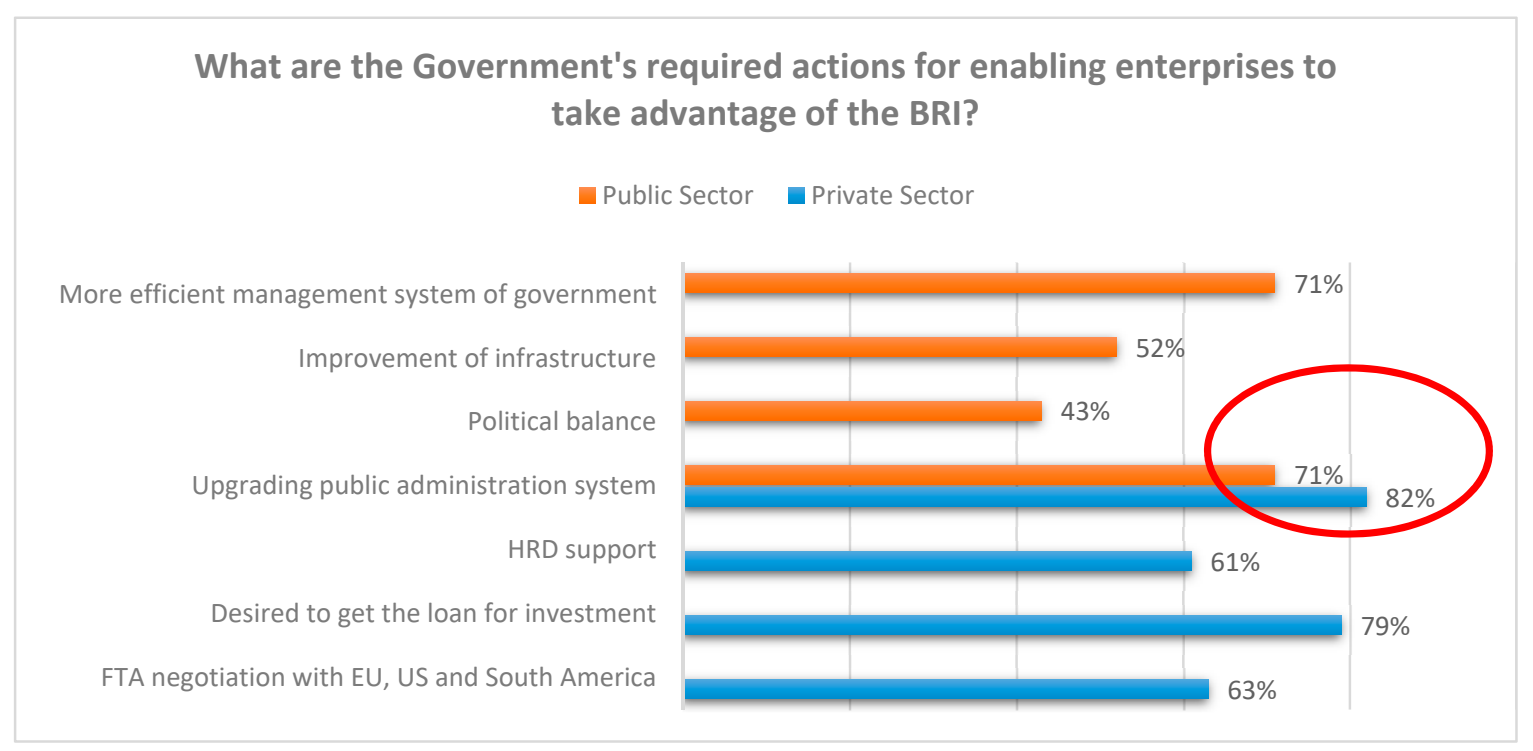

Figure 8. Improving the existing public administration system becomes crucial (Source: Authors' analysis).

Overall, respondents from public sectors are looking for actions at a more macro level such as budget management, infrastructure, and political-related matters. This is no surprise when the private sector tend to be practical with expectations that enables them to be more competitive. The private sector considers the BRI as opportunities while the State sectors consider the BRI as challenges.

\section{Conclusions}

The present study qualitatively investigated perceptions of the Belt and Road Initiative with a focus on Vietnamese enterprises in the textile and garment industry. Overall, the initiative is perceived as beneficial for infrastructure development, in general, and for the promotion of Vietnamese textile exports in particular. 
The Belt and Road Initiative is an ambiguous initiative bundled with opportunities and challenges. In order to take advantage of benefits that the policy may bring to the Vietnamese textile industry, informed actions of Government and enterprises should be taken. To be specific, for the Vietnamese government, an efficient and upgraded public administration is ubiquitously perceived as indispensable. In addition, textile and garment enterprises should focus on building a strong domestic brand, human resources, and establishing an ODM and OBM business model. Although the latter may be overlooked by state officials, it is considered as an important strategy in the context of increasing needs for streamlined supply chains in textile manufacturing enterprises.

The BRI may accompany a number of challenges. The first and foremost is the lack of competitiveness of local textile producers. To anticipate, it is suggested that the textile and apparel businesses should actively combine value chains, technology, and management solutions to improve labor productivity, and in turn reduce marginal costs to compete with the upcoming influx of cheap products from the BRI regions. In addition, environmental concerns and FDI-loan issues should also be considered and carefully examined by further research attempts incorporating three parties: the government, the academics, and the enterprises.

Author Contributions: Investigation, V.A.T.; B.L.N.D.; Writing—Original draft, Q.A.L.

Funding: This research received no external funding.

Conflicts of Interest: The authors declare no conflict of interest.

\section{References}

1. Tao, X. Back on the Silk Road: China's Version of a Rebalance to Asia. Glob. Asia 2014, 9, 70-76.

2. General Statistics Office of Vietnam. Social and Economic Situation in 2018. Available online: https: $/ /$ www.gso.gov.vn/default_en.aspx?tabid=622\&ItemID=19043 (accessed on 15 December 2018).

3. Customs Statistics of Vietnam. Export Statistics in 2018. Available online: https://www.customs.gov.vn/Lists/ ThongKeHaiQuanLichCongBo/Attachments/1155/2018-T12T-2X(VN-SB).pdf (accessed on 20 July 2019).

4. Wang, C.; Wang, L.; Liu, X.; Du, C.; Ding, D.; Jia, J.; Yan, Y.; Wu, G. Carbon footprint of textile throughout its life cycle: A case study of Chinese cotton shirts. J. Clean. Prod. 2015, 108, 464-475. [CrossRef]

5. Tracy, E.F.; Shvarts, E.; Simonov, E.; Babenko, M. China's new Eurasian ambitions: The environmental risks of the Silk Road Economic Belt. Eurasian Geogr. Econ. 2017, 58, 56-88. [CrossRef]

6. Yu, H. Motivation behind China's 'One Belt, One Road' Initiatives and Establishment of the Asian Infrastructure Investment Bank. J. Contemp. China 2017, 26, 353-368. [CrossRef]

7. Blanchard, J.-M.F. Probing China's Twenty-First-Century Maritime Silk Road Initiative (MSRI): An Examination of MSRI Narratives. Geopolitics 2017, 22, 246-268. [CrossRef]

8. Callaghan, M.; Hubbard, P. The Asian Infrastructure Investment Bank: Multilateralism on the Silk Road. China Econ. J. 2016, 9, 116-139. [CrossRef]

9. Czerewacz-Filipowicz, K. The Eurasian Economic Union as an Element of the Belt and Road Initiative. Comp. Econ. Res. Cent. East. Eur. 2019, 22, 23-37.

10. Derudder, B.; Liu, X.; Kunaka, C. Connectivity Along Overland Corridors of the The Belt and Road Initiative. World Bank Discussion Paper 2018. Available online: http://documents.worldbank.org/curated/ en/264651538637972468/pdf/130490-MTI-Discussion-Paper-6-Final.pdf (accessed on 20 July 2019).

11. Sial, S. The China-Pakistan Economic Corridor: An assessment of potential threats and constraints. Confl. Peace Stud. 2014, 6, 24.

12. Karim, M.A.; Islam, F. Bangladesh-China-India-Myanmar (BCIM) Economic Corridor: Challenges and prospects. Korean J. Def. Anal. 2018, 30, 283-302.

13. Ascensão, F.; Fahrig, L.; Clevenger, A.P.; Corlett, R.T.; Jaeger, J.A.G.; Laurance, W.F.; Pereira, H.M. Environmental challenges for the The Belt and Road Initiative. Nat. Sustain. 2018, 1, 206-209. [CrossRef]

14. Wan, M. The Asian Infrastructure Investment Bank: The Construction of Power and the Struggle for the East Asian International Order; Palgrave Macmillan: Basingstoke, UK, 2016.

15. Cai, P. Understanding China's The Belt and Road Initiative. Available online: https://think-asia.org/handle/ 11540/6810 (accessed on 20 July 2019). 
16. Zhai, F. China's the Belt and Road Initiative: A preliminary quantitative assessment. J. Asian Econ. 2018, 55, 84-92. [CrossRef]

17. Wang, Y. Offensive for defensive: The the Belt and Road Initiative and China's new grand strategy. Pac. Rev. 2016, 29, 455-463. [CrossRef]

18. Tekdal, V. China's The Belt and Road Initiative: At the crossroads of challenges and ambitions. Pac. Rev. 2018, 31, 373-390. [CrossRef]

19. Chen, S. Regional Responses to China's Maritime Silk Road Initiative in Southeast Asia. J. Contemp. China 2018, 27, 344-361. [CrossRef]

20. Joshi, P. The Chinese Silk Road in South \& Southeast Asia: Enter "Counter Geopolitics". IndraStra Glob. 2016, 3,4 .

21. Joycee, A.T. Maintaining ASEAN Centrality in Connectivity through MPAC. CIRSS Comment. $2015,2$. Available online: http://www.fsi.gov.ph/maintaining-asean-centrality-in-connectivity-through-mpac-byjoycee-a-teodoro-vol-ii-no-17-june-2015/ (accessed on 20 July 2019).

22. Hiep, L.H. The The Belt and Road Initiative in Vietnam: Challenges and Prospects. ISEAS Perspective. Available online: https:/think-asia.org/handle/11540/8138 (accessed on 15 December 2019).

23. The Vietnam Textile and Apparel Association. Annual Report of 2017. Available online: http://www.vietnamtextile.org.vn/ban-tin-thong-ke_p1_1-1_2-1_3-633_9-2_11-10_12-27_13-620. html\#a_list_target (accessed on 20 July 2019).

24. World Bank. Doing Business 2014: Understanding Regulations for Small and Medium-Size Enterprises. Available online: http://www.doingbusiness.org/en/reports/global-reports/doing-business-2014 (accessed on 20 July 2019).

25. James, V.; Erwin, C.; Juzhong, Z. The One Belt One Road Initiative and Its Impacts on Growth and Trade. In Proceedings of the 19th Annual Conference on Global Economic Analysis, Washington, DC, USA, 15-17 June 2016.

26. Ravelo, J.L. Mapping the Environmental Impacts of China's Textile Industry. Available online: https://www.devex.com/news/sponsored/mapping-the-environmental-impacts-of-china-s-textileindustry-91905 (accessed on 31 July 2019).

(C) 2019 by the authors. Licensee MDPI, Basel, Switzerland. This article is an open access article distributed under the terms and conditions of the Creative Commons Attribution (CC BY) license (http://creativecommons.org/licenses/by/4.0/). 